\title{
Investigation of some neutronic calculations for vanadium carbide cladding material in a boiling water reactor modelling
}

\author{
Mehtap Düz \\ İnönü University, Faculty of Arts and Sciences, Department of Physics, Malatya, Turkey \\ Received: 13 June 2021, Accepted: 16 June 2021 \\ Published online: 8 July 2021.
}

\begin{abstract}
In this study, a boiling water reactor was modelled and Vanadium Carbide (VC) was used as cladding material in the design. In the designed reactor core, small squares lattices were placed in square lattices. Neptunium mixed fuel rod, VC cladding material, water cooler were used in each small square lattice. $\mathrm{NpO}_{2}$ and $\mathrm{NpF}_{4}$ fuels were used as the Neptunium mixture in the fuel rods. In this study, the criticality $\left(\mathrm{k}_{e f f}\right)$, neutron flux, fission energy, heating and deposition values were investigated for the VC cladding material. In the research, the reactor design was made in three dimensions using MCNPX-2.7.0 Monre Carlo code and ENDF/B-VII library.
\end{abstract}

Keywords: Keff, MCNPX-2.7.0, cladding material.

\section{Introduction}

Fission reactors developed with the discovery of the fission reaction constitute all of the existing reactors in operation in the world. Light water reactors (LWR) from fission reactors; boiling water reactors (BWR) and pressurized water reactors (PWR) [1,2]. While fission reactors have the advantage of high energy production with the use of uranium fuel, they have a disadvantage with long half-life waste. From the fission reactors, uranium (about $95 \mathrm{wt} \%$ ), plutonium $(0.9$ wt\%), minor actinides; $\mathrm{Np}, \mathrm{Am}$ and $\mathrm{Cm}(0.1 \mathrm{wt} \%)$ and fission products such as $\mathrm{Cs}, \mathrm{Sr}, \mathrm{Tc}$ and $\mathrm{I}(4 \mathrm{wt} \%)$ are left as nuclear waste [3,4]. It is desirable to transform these long half-lived wastes into stable or short half-life cores.

The fact that the uranium fuel reserve will be depleted in the near future has led the scientific world to seek new alternative fuels in fission reactors. Studies have shown that minor actinides released as waste have high power and radiotoxicity. For this reason, recent studies have focused on the production of alternative fuels by reusing minor actinides left as waste as fuel in fission reactors. Thus, it is thought that the amount of minor actinide waste will decrease as well as energy and fuel production.

The select of fuel cladding is an important parameter in reactor physics. Fuel cladding material; it should have low neutron absorption cross section, resistant to any corrosion, and low cost characteristics [5-8]. In this study, VC (5.1 barn) [9] cladding material with these properties was used as clad around the fuel rod to generate energy.

In this study, using $\mathrm{NpO}_{2}$ and $\mathrm{NpF}_{4}$ as fuel to reduce minor actinide amount and $\mathrm{VC}$ as cladding material for low thermal neutron cross section, a three-dimensional BWR reactor core design was made with Monte Carlo method and some neutronic calculations were investigated.

\footnotetext{
*Corresponding author e-mail: mehtap.gunay@inonu.edu.tr
} 


\section{Material and methods}

In this study, the designed reactor is in the form of a core cylinder. The radius of the cylinder is $264.08 \mathrm{~cm}$ and its height is $365.76 \mathrm{~cm} .5 \mathrm{~cm}$ thick SS316LN ferritic steel was used as reflector and $\mathrm{B}_{4} \mathrm{C}$ as control rod. In Figure 1, the reactor core was divided into $8 \times 8$ square lattices, each $30.48 \mathrm{~cm}$ wide. A 7x7 small square lattice, each $1.94084 \mathrm{~cm}$ wide, was placed in each square lattice. In Figure 2, 0.2-1\% $\mathrm{NpO}_{2}$ and $\mathrm{NpF}_{4}$ fuel rod radius is $0.60579 \mathrm{~cm}$, gap width is $0.01524 \mathrm{~cm}$, VC clad radius is $0.71501 \mathrm{~cm}$.

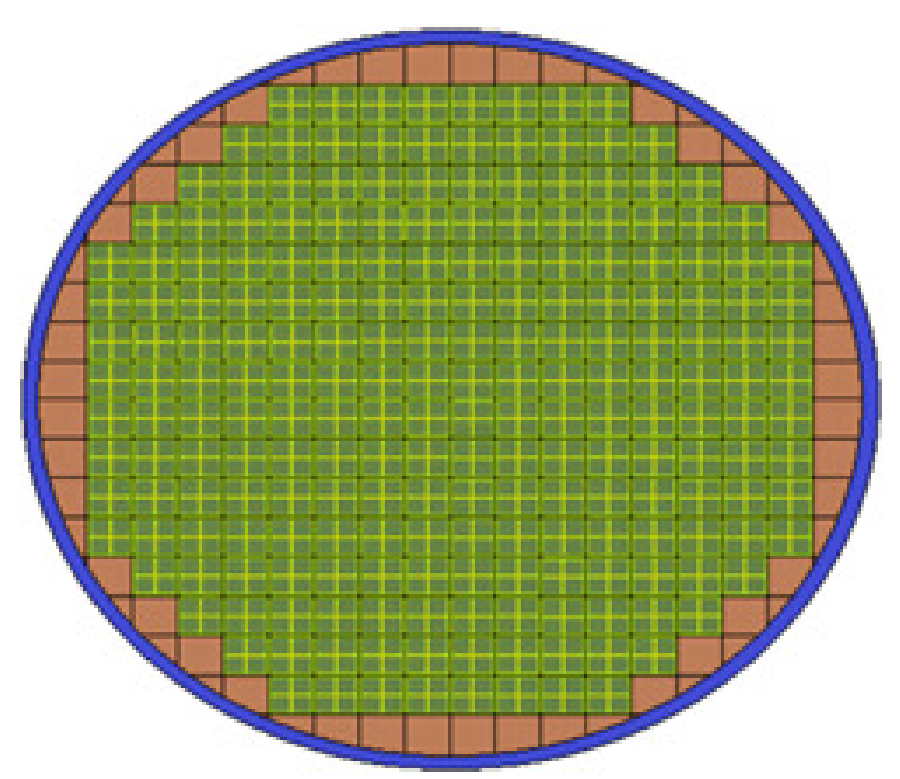

Fig. 1: Reactor core design

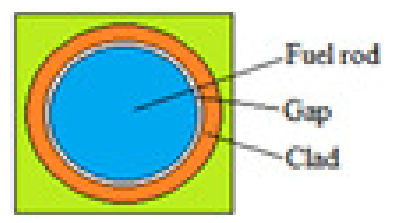

Fig. 2: Cell geometry

Monte Carlo method used in the study; it is a computer program that models a complex event or experiment using statistical methods. Since it is a powerful method, it is used to calculate the properties of multi-element systems. Monte Carlo method is a method in which random numbers are generated and accordingly, it is desired to simulate predicted processes. Similarities are tried to be established in order to solve the problem by considering the possibilities. When combined with the MCNP code, which is successful in radiation transmission at low energies in nuclear engineering, with the LAHET (Los Alamos High Energy Transport) code used in high energy radiation transmission, the particles can be transmitted fully at almost all energies. MCNPX; it was created by combining MCNP and LAHET codes. The combination of the two codes, MCNPX, has allowed full radiation transmission in high energy applications in nuclear engineering $[10,11]$. 


\section{Results}

In this study, $\mathrm{k}_{\text {eff }}$, neutron flux, fission energy, heating and deposition values were calculated for VC cladding material and $\mathrm{NpO}_{2}$ and $\mathrm{NpF}_{4}$ fuels.

Figure 3-7 shows $\mathrm{k}_{\text {eff }}$, neutron flux, fission energy, heating and deposition for $\mathrm{VC}$ cladding material and $\mathrm{NpO}_{2}$ and $\mathrm{NpF}_{4}$ fuels. As can be seen from Figure 3-7, as the fuel ratios for VC cladding material increase, $\mathrm{k}_{e f f}$, neutron flux, fission energy, heating and deposition increase respectively. For VC cladding material, the highest $\mathrm{k}_{\text {eff }}$, neutron flux, fission energy, heating and deposition were obtained from $0.75 \% \mathrm{NpO}_{2}$ fuel, and the lowest $\mathrm{k}_{\text {eff }}$, neutron flux, fission energy, heating and deposition were obtained from $0.65 \% \mathrm{NpF}_{4}$ fuel.

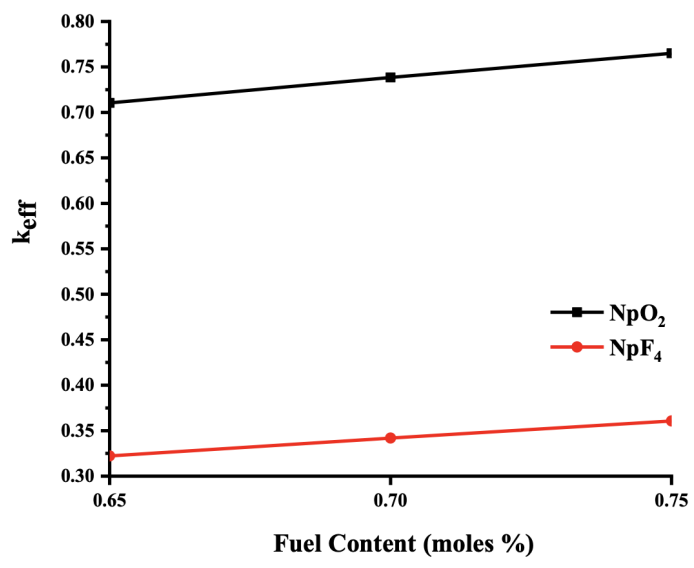

Fig. 3: $\mathrm{k}_{\text {eff }}$ values for $\mathrm{VC}$ clad, the fuel components $\mathrm{NpO}_{2}$ and $\mathrm{NpF}_{4}$.

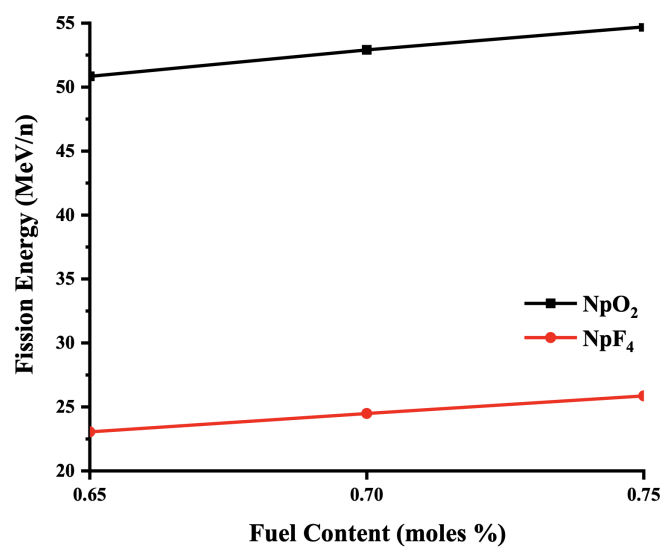

Fig. 5: The fission energyvalues for $\mathrm{VC}$ clad, the fuel components $\mathrm{NpO}_{2}$ and $\mathrm{NpF}_{4}$

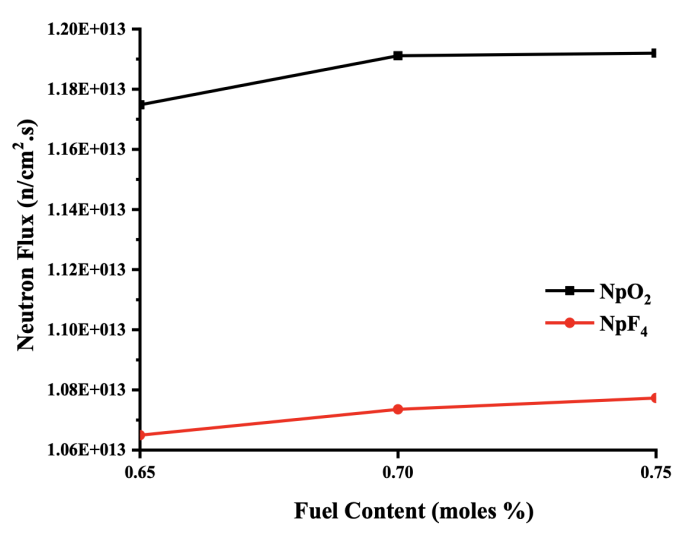

Fig. 4: The neutron flux values for $\mathrm{VC}$ clad blah the fuel components $\mathrm{NpO}_{2}$ and $\mathrm{NpF}_{4}$

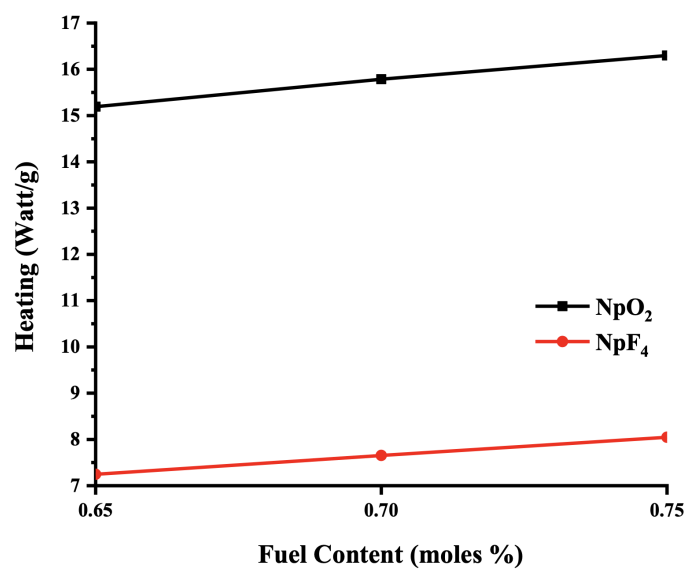

Fig. 6: The heating values for $\mathrm{VC}$ clad, the fuel components $\mathrm{NpO}_{2}$ and $\mathrm{NpF}_{4}$ 


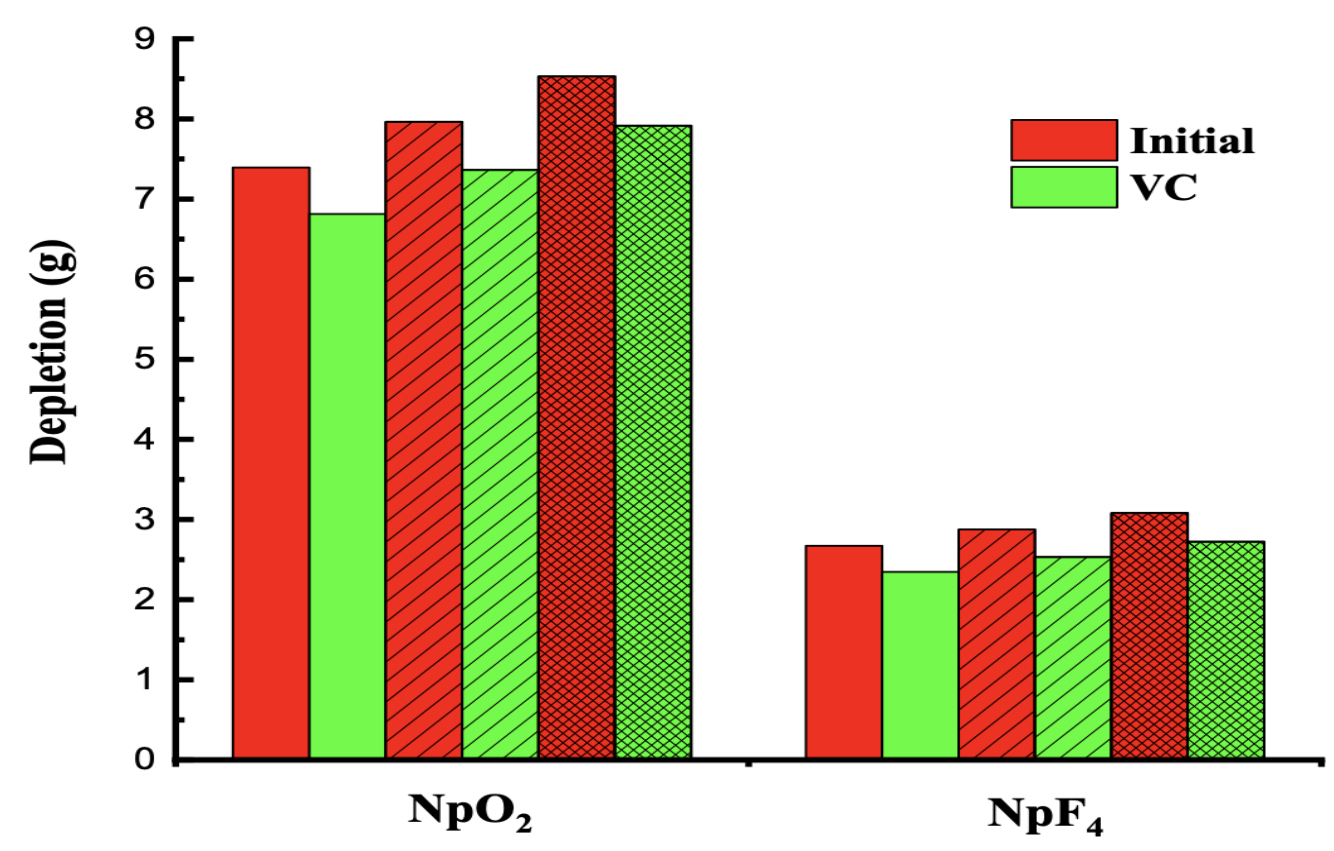

Fig. 7: The depletion values for $\mathrm{VC}$ clad, the fuel components $\mathrm{NpO}_{2}$ and $\mathrm{NpF}_{4}(0.65 \%$

$0.7 \%$

$0.75 \%$

\section{Conclusion}

In this study, $\mathrm{k}_{\text {eff }}$, neutron flux, fission energy, heating and deposition values were calculated by using $\mathrm{NpO}_{2}$ and $\mathrm{NpF}_{4}$ fuels for VC cladding material. In the study, MCNPX-2.7.0 Monte Carlo code and ENDF/B-VII library were used for three-dimensional BWR design.

When $0.75 \% \mathrm{NpO}_{2}$ fuel was used for the $\mathrm{VC}$ cladding material, the $\mathrm{k}_{e f f}$, neutron flux, fission energy, heating and deposition values were higher than $\mathrm{NpF}_{4}$. As a result; based on the data obtained from neutronic calculations, it can be said that it is more appropriate to use $\mathrm{VC}$ clad $\mathrm{NpO}_{2}$ fuel in $\mathrm{BWR}$ reactors.

\section{Competing interests}

The authors declare that they have no competing interests.

\section{Authors' contributions}

All authors have contributed to all parts of the article. All authors read and approved the final manuscript.

\section{References}

[1] Düz, M. (2021). Neutronic Calculations for The Certain Americium Mixed Fuels and Clads in a Boiling Water Reactor. Frontiers in Energy Research. doi: 10.3389/fenrg.2021.639416 
[2] Düz, M. \& İnal, S. (2020). The effect of different fuels and clads on neutronic calculations in a boiling water reactor using the Monte Carlo method. Scientific Reports. doi: 10.1038/s41598-020-79236-8

[3] Warin, D. Status of the French research program on partitioning and transmutation. J. Nucl. Sci. Technol. 44, 410-414 (2007).

[4] IAEA, International Atomic Energy Agency. Status of Minor Actinide Fuel Development. Nuclear Energy Series No. NF-T-4.6. (IAEA Publishing, Vienna, 2009).

[5] Edsinger, K. \& Murty, K.L. (2001). LWR pellet-cladding interactions: materials solutions to SCC. JOM. 53, 9-13. doi:10.1007/s11837-001-0079-7

[6] Jha, S.K., Dixit, S., Chetan, K., Vaibhaw, K., Srivastava, D. (2019). Co-extrusion of Zircaloy-2 and Zr-Sn alloy for double clad tube manufacturing: Numerical simulation and experimental validation. J. Manuf. Process. 39, 18-25. doi:10.1016/j.jmapro.2019.01.048

[7] Singh, G., Gorton, J., Schappel, D., Brown, N.R., Katoh, Y., Wirth, B.D., and Terrani, K.A. (2019). Deformation analysis of SiC-SiC channel box for BWR applications. J. Nucl. Mater. 513, 71-85. doi:10.1016/j.jnucmat.2018.10.045

[8] Williams, C.D., Marlowe, M.O., Adamson, R.B., Wisner, S.B., Rand, R.A., Armijo, J.S. (1996). ”Zircaloy-2 lined zirconium barrier fuel cladding," in Twelfth International Symposium. ASTM STP. 1295, 676-694. doi:10.1520/STP16196S

[9] Finley, J. J., Korchynsky, M., and Sarian, S. (1960). "Columbium alloy clad uranium carbide fuel element”. United States Atomic Energy Commission. New York, NY:Union Carbide Metal Company), 31.

[10] Waters, L.S. (ed.). MCNPX User's Manual, Version 2.3.0. LA-UR-02-2607 (2002).

[11] Prael, R.E., Lichtenstein, H. User Guide to LCS: The LAHET Code System, Los Alamos National Laboratory Report. LA-UR-893014 (1989). 